\title{
Disruption in Economies, Industries, and Political Affairs: Can Postsecondary Education Be Far Behind?
}

\author{
Libby V. Morris ${ }^{1}$ \\ Published online: 2 December 2016 \\ (C) Springer Science+Business Media New York 2016
}

Around the world we see disruptions in industries, economies, governments, and social structures. Over the past four decades, dramatic changes in manufacturing, shifts in financial markets, the migration of people, and the movement of products created global markets hereto-fore unseen and still incompletely understood. In the U.S., effects of the long and slow drain of manufacturing jobs to other parts of the world came to a head with the U.S. banking crisis and the housing bust. New technology based jobs favored the college educated and left many others behind.

In Europe, cross country collaboration and economic ties were increasingly strained by migration, challenges to the euro, and deficits across the Eurozone. In spring 2016, the United Kingdom voted to leave the European Union (the Brexit vote) after over 40 years as a member. In 2015, Greece was offered a bailout (almost $\$ 100$ billion), its third since 2010; and the debt crisis continues. In 2016 in the midst of deep divisions over social issues, economic policies, and foreign affairs the United States elected a real-estate developer and reality television figure as its 45th President. This result shocked pollsters and many in academe as this selection stands in sharp contrast to the experience and demeanor of prior leaders and the current president, Barack Obama.

The push and pull of nationalism and globalism are vocal and make public the intense stress in individuals and institutions nationwide and globally; disruption is occurring in subtle and dramatic ways. Bombings and acts of violence occur in the most advanced and least developed nations. Cyberattacks and human aggressions are reported on social media, in newspapers, and on the airwaves. Some children around the globe must think war, poverty, and lack of food and housing are normal; it has been their entire existence.

People in the U.S., Europe and other advanced economies, who for the most part have clean water and air, easier access to food and housing, and relative safety and freedoms, express dissatisfaction with life circumstances, corporate changes, and governmental actions, whether they lean to the right, left, or straight down the middle of the political spectrum. Increasingly,

Libby V. Morris

1vmorris@uga.edu 
little agreement exists on the origins and extent of contemporary societal problems and especially their solutions.

Postsecondary education needs to take note. Year after year, faculty members focus on "our courses, our students, and our fields." Those of us in higher education do think deeply about the condition of the nation and world; about the current generation of students; and how to educate for critical thinking, civic engagement, and career preparation. Yet we are embedded in our disciplinary areas, and our attention and perspectives are informed by our professional associations, our colleagues, and our academic institutions. Contrary to some popular reports, there is ideological diversity across the more than 700,000 full-time college and university faculty members; however, the larger issues that are generally most important to us are those that cut across our professional fields-trade and finance in business and economics, climate change in geography and earth sciences, health care in pharmaceutical and medical fields, schooling in social sciences and education, and so on. These cutting issues of education, health, global markets, employment, and migration affect us all. We know there is no returning to a simpler time.

The current problems of higher education may not reach the level of "disruption;" but change, probably rapid change, is on the horizon. While access to college has broadened (put a check mark in the improvement category), retention and persistence to graduation continue to fall below national and state targets and student expectations. Overall, 60\% of all first-time, full-time undergraduates receive a degree within six years; 4 in 10 do not graduate. Rising tuition and fees exacerbate the stress and long-term effects of college attendance; currently, approximately 44 million borrowers hold student loan debt totaling more than $\$ 1.3$ trillion dollars. The problem of how to graduate the next generation on time and without crushing debt is on the national agenda - so much so that a 2016 U.S. presidential candidate called for college to be tuition free and debt free. A disruptive policy proposal-yes; widely supported among college goers-yes.

Access, retention, graduation, and the cost of attendance are overarching issues that vary immensely across the approximately 4,800 public and private 2-year, 4-year, and research institutions. The $20+$ million college students are equally diverse in academic preparation, educational interests, ability to pay, full-time and part-time status, age, and socioeconomic status. This diversity in students and institutions is ripe for innovation. Experiments on structure, content, and assessment could help us to better understand and enable retention, graduation, and efficiency in time-to-degree and costs. Continued mimetic behavior across institutions will not bring about change; it will only serve to maintain the status quo of structure, outcomes, and costs.

It is time for innovation in the structure of the college curriculum writ broadly; time to think creatively from the course level through programs to the institutional level. Only when we diversify the content and structure will we find resolutions to the overarching issues and serve effectively the diversity in the student population. The century old Carnegie unit brought important standardization to education: it likely was revolutionary, maybe disruptive, in its time; and it remains a "central organizing feature" in American education (see https://www. carnegiefoundation.org/resources/publications/carnegie-unit/). MOOCs may ultimately be disruptive, and we know that online education challenges our ideas of contact, "seat-time," and quality. Which colleges and universities will venture to invest in change? To dedicate the time, collaborative spirit, rewards, and courage to radically rethink what we find normative today? Leaders will be required to do so. The faculty should step up.

Look at the world! Postsecondary education needs to take note - in my opinion. 